\title{
Effect of an MDP-containing Primer on the Bond Strength Between Ten Different Resin Cements and Air-abraded Monolithic Zirconia
}

\author{
MDP Içerikli Primerin On Farklı Rezin Siman ve Kumlanmış \\ Monolitik Zirkonya Arasındaki Bağlanma Dayanımına Etkisi
}

\author{
(1) Yener Okutan ${ }^{1}$, (1) Münir Tolga Yücel2 ${ }^{2}$, (1) Mustafa Borga Dönmez ${ }^{3}$, (1) Tuğçe Gezer ${ }^{4}$ \\ ${ }^{1}$ Aydın Adnan Menderes University Faculty of Dentistry, Department of Prosthodontics, Aydın, Turkey \\ ${ }^{2}$ Selcuk University Faculty of Dentistry, Department of Prosthodontics, Konya, Turkey \\ ${ }^{3}$ Biruni University Faculty of Dentistry, Department of Prosthodontics, Turkey \\ ${ }^{4}$ Eyüpsultan Oral and Dental Health Center, Clinic of Prosthodontics, İstanbul, Turkey
}

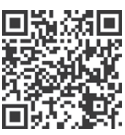

Keywords

Air-abrasion, MDP, monolithic zirconia, primer, resin cement

Anahtar Kelimeler

Kumlama, MDP, primer, monolitik zirkonya, rezin siman

Received/Geliş Tarihi : 27.01.2021

Accepted/Kabul Tarihi : 10.03.2021

doi:10.4274/meandros.galenos.2021.03411

Address for Correspondence/Yazışma Adresi: Yener Okutan DDS, PhD,

Aydın Adnan Menderes University Faculty of Dentistry, Department of Prosthodontics, Aydın, Turkey

Phone : +90 2562133939

E-mail : yenerokutan@hotmail.com

ORCID ID: orcid.org/0000-0002-7188-4929

(C) Meandros Medical and Dental Journal, Published by Galenos Publishing House.

This is article distributed under the terms of the Creative Commons Attribution NonCommercial 4.0

International Licence (CC BY-NC 4.0).

\section{Abstract}

Objective: The aim of the present study was to evaluate the shear bond strength (SBS) of different self-adhesive luting systems to airborne-particleabraded monolithic zirconia ceramic, with or without the application of a 10-methacryloyloxydecyl dihydrogen phosphate (MDP)-based ceramic primer.

Materials and Methods: A total of 200 monolithic zirconia specimens were prepared and air-abraded using $50-\mu \mathrm{m}$ aluminum oxide particles under a pressure of 2.5 bar. Ten different self-adhesive resin cements were then bonded to the zirconia specimens with or without the use of an MDP-containing primer. After $24 \mathrm{~h}$ of water storage, all of the resin-bonded samples were thermocycled 5,000 times $\left(5-55^{\circ} \mathrm{C}\right)$. The SBS of the specimens was measured using a universal testing machine, and failure types were examined under a stereomicroscope. The data were statistically analyzed using two-way ANOVA and Tukey's honestly significant difference tests.

Results: Statistical analyses revealed significant differences between the different resin cement groups $(p<0.001)$. All of the primer-applied groups showed statistically higher SBS values than the non-primed groups $(p<0.05)$. The SBS values of primerapplied groups ranged between $8.56 \pm 0.91$ and $16.08 \pm 0.67 \mathrm{MPa}$. Adhesive failures were more predominant in the nonprimed groups than in the primed groups for each resin cement tested. MDP-based resin cements used did not result in the highest bond strengths.

Conclusion: In the case of every self-adhesive resin cement tested, application of an additional MDP-containing priming agent yielded enhanced bond strength to air-abraded monolithic zirconia specimens. However, no association between the MDP content of the resin cements and the SBS values was observed.

Öz

Amaç: Bu çalışmanın amacı kendinden adezivli farklı yapıştırma sistemlerinin kumlanmış monolitik zirkonyaya bağlanma dayanımını (SBS) metakriloiloksidesil dihidrojen fosfat (MDP) esaslı seramik primeri uygulaması yaparak veya yapmadan değerlendirmektir. 
Gereç ve Yöntemler: Toplamda 200 adet monolitik zirkonya örneği hazırlandı ve $50-\mu m$ alüminyum oksit kumu kullanılarak 2,5 bar basınç altında kumlandı. Daha sonra, 10 farklı kendinden adezivli rezin siman MDP içerikli primer uygulaması yapılarak veya yapılmadan zirkonya örneklere bağlandı. Rezin uygulanmış örneklere 24 saat suda bekleme süresinden sonra 5.000 termal döngü (5$55^{\circ} \mathrm{C}$ ) uygulandı. Örneklerin SBS değerleri evrensel bir test makinesi kullanılarak ölçüldü. Başarısızlık tipleri stereomikroskop altında incelendi. Veriler iki-yönlü ANOVA ve Tukey dürüstçe anlamlı fark testleri kullanılarak istatistiksel olarak analiz edildi.

Bulgular: İstatistiksel analizler farklı rezin siman grupları arasında önemli farklılıklar olduğunu ortaya koymuştur ( $<<0,001)$. Bütün primer uygulanmış gruplar, primer uygulanmamış olanlara göre daha fazla SBS değerleri göstermiştir $(p<0,05)$. Primer uygulanan grupların SBS değerleri $8,56 \pm 0,91 \mathrm{MPa}$ ve $16,08 \pm 0,67 \mathrm{MPa}$ arasında değişmiştir. Her bir rezin siman için primer uygulanmayan gruplarda primer uygulananlara göre adeziv başarısızlık daha fazla görülmüştür. MDP esaslı rezin simanların kullanımı ile en yüksek bağlanma dayanımı elde edilmemiştir.

Sonuç: MDP içerikli primer ajanı uygulaması ile test edilen bütün rezin simanlar için önceden kumlanmış monolitik zirkonya örneklere daha fazla bağlanma dayanımı elde edilmiştir. Ancak, rezin simanların MDP içeriği ile SBS değerleri arasında bir ilişki bulunmamıştır.

\section{Introduction}

In recent years, use of the yttria-tetragonal zirconia polycrystal (Y-TZP) has become widespread as a metal-free alternative in fixed dental prosthesis due to its superior mechanical properties (1,2). Depending on the specific composition of sintered zirconia ceramics, fracture strength can be $>1.000 \mathrm{MPa}$ $(3,4)$. Computer aided design/manufacturing technologies have resulted in ease-of-use with this highly crystalline material, allowing the fabrication of fitting frameworks $(5,6)$. Covering these high-strength $Y$-TZP infrastructures with veneering ceramics that offer improved aesthetics is a frequently used process $(7,8)$. However, some studies have reported that such a multilayered structure may cause some major problems including chipping, cracking, or delamination of veneering porcelain (8-10). To overcome these challenges, monolithic zirconia has recently been considered a viable alternative in fabricating both tooth and implant-supported full-contour ceramic restorations $(11,12)$. Another advantage of monolithic zirconia materials was shown in an earlier study, with the results indicating that such restorations can withstand forces in the molar region even at a reduced thickness. Therefore, limiting the abutment preparation can preserve both the tooth substance and the axial height, promoting retention and resistance (12).

The success of zirconia-based restorations is highly dependent on achieving a reliable adhesion between the zirconia and resin cement. A strong adhesion of luting cements to the restoration improves marginal adaptation, prevenents microleakage, and increases retention where sufficient mechanical retention does not exist (13). Unfortunately, unlike glass ceramics, zirconia is an acid-resistant and non-etchable material (14) because of its glass-free, polycrystalline microstructure (15), and therefore requires more aggresive treatment methods (16). Airborne-particle abrasion, one of the common surface treatment methods for zirconia, creates micron-sized rough areas that provide an increased surface area required for micro-mechanical interlocking $(17,18)$. The effects of this treatment are still controversial with some studies showing a strength-reducing effect that may be related to deep surface flaws which act as stress concentrators $(19,20)$; on the contrary, others have reported a strengthening effect which may be due to a compressive layer formed via tetragonal to monoclinic phase transformation $(4,21)$. This stress-induced transformation leads to a volume expansion which generates compressive stresses, thereby closing the crack tip and preventing further crack propagation (2). In fact, the relative importance of these countervailing effects may depend on the material microstructure and the severity of the air-abrasion treatment $(4,19)$. Therefore, to minimize possible surface damage, application of air-abrasion treatments at moderate or low pressures has been recommended (22-24).

In addition to damage-inducing effects, surface roughening using airborne-particle abrasion may not always produce a reliable bond between resin and zirconia $(16,25)$. Application of a primer onto the zirconia surface can improve the resin-bond strength, via chemical interaction between the ceramic surface and the applied resin cement $(23,25,26)$. The 10-methacryloyloxydecyl dihydrogen phosphate (MDP) monomer has been used by several investigators for this purpose (25-30), with effective bonding between the MDP acidic groups (phosphoric acid) and the oxide layer of the zirconia. 
It was previously noted that chemical bonding to oxide ceramics obtained through the use of primers promotes long-term success under clinical conditions (22). However, the findings of another study indicated that without airborne-particle abrasion, MDPcontaining materials were not capable of maintaining durable long-term adhesion (29). Overall, limited information is available regarding the use of MDPcontaining primers in combination with air-particle abrasion. Therefore, to guide clinical practice, it would be useful to assess whether the use of an MDP primer applied to the airborne-particle-abraded zirconia surface is beneficial compared to air-abrasion treatment alone. Clearfil ceramic primer plus, a commercially available priming agent, contains a silane bi-functional molecule; however, it is not wellunderstood if MDP in combination with silane has a synergistic or antagonistic bond-promoting effect (31).

The choice of the most proper cement is a prerequisite for efficient bonding between resin and zirconia (32). Conventional resin cements require independent pretreatment procedures such as etching, priming, and bonding to achieve adequate adhesion; therefore, this multi-step cementation procedure is technique-sensitive, unpredictable, and time-consuming. To simplify the process, self-adhesive resin cements that rely on a single-step process have been suggested for luting of zirconia-based restorations $(18,32,33)$. The resin matrix of these systems contains multifunctional acid methacrylates that react with the substrate to improve adhesion (32). In addition, various self-adhesive resin cements consist of phosphate monomer, including MDP. Although manufacturers suggest that clinicians may apply self-adhesive resin cements to Y-TZP without an additional primer $(18,34)$, there is no sufficient information regarding the bonding efficiency of phosphate monomers in self-adhesive resin cements (34). Further, because of the limited information available regarding the use of MDP-based primers on zirconia combined with self-adhesive resin cements, investigations in this area are necessary.

The purpose of the present study was to investigate the shear bond strength (SBS) of different self-adhesive resin cements to air-abraded monolithic zirconia ceramics with or without application of an MDP-containing ceramic primer. The two null hyphotheses were that (i) there would be no difference between the SBS values of different resin cements and (ii) the application of MDP-containing primer would not change the SBS values.

\section{Materials and Methods}

\section{Preparation of Zirconia Specimens}

A total of 200 rectangular-shaped specimens were cut from a monolithic Y-TZP ceramic block (Zenostar T, Wieland Dental GmbH, Pforzheim, Germany) using a water-cooled low speed diamond saw (Isomet, Buehler Ltd., Lake Bluff, IL, USA) and polished manually with $600,1,000$, and 1,200-grit silicon carbide abrasive papers (English Abrasives \& Chemicals Ltd., London, UK) under running water to obtain standardized smooth surfaces. Next, all the specimens were sintered to full density following the manufacturer's instructions. 2-mm-thick slices were carefully embedded in autopolymerysing acrylic resin, and one surface of the sample was left uncovered to adhere to the resin cement. The zirconia surfaces were airborne-particle-abraded with $50-\mu \mathrm{m} \quad \mathrm{Al}_{2} \mathrm{O}_{3}$ particles (Mega Strahlkorund, Mega Dental, Budingen, Germany), under a 2.5-bar pressure for $15 \mathrm{~s}$. The samples were placed at a distance of $10 \mathrm{~mm}$ from the handpiece of the sandblaster unit (Bego Easyblast, Bego, Germany) during the air-abrasion treatment. All the surface-treated zirconia specimens were cleaned ultrasonically with $96 \%$ isopropanol for $180 \mathrm{~s}$ in an ultrasonic cleaner (Whaledent Biosonic, Whaledent Inc., New York, USA) and air-dried to remove the debris of aluminum oxide particles from the ceramic surface. The specimens were then randomly divided into 20 subgroups, each containing 10 specimens, based on the 10 different self-adhesive resin cements combined with or without primer application. The manufacturers and compositions of the resin materials used in the study are summarized in Table 1.

\section{Bonding, Thermocycling, and Shear Bond Strength Test Procedures}

First, an MDP-containing primer (Clearfil Ceramic Primer Plus, Kuraray Noritake, Okayama, Japan) was applied on one half of the air-abraded zirconia specimens in each resin cement group using an applicator microbrush, and the adherent surfaces were dried sufficiently using oil-free air. Subsequently, specific teflon molds possesing a central cylindirical 


\begin{tabular}{|c|c|c|}
\hline Self-adhesive resin cement & Manufacturer & Main composition \\
\hline RelyX U200 & $\begin{array}{l}\text { 3M ESPE, St.Paul, } \\
\text { MN, USA }\end{array}$ & $\begin{array}{l}\text { Methacrylate monomers containing phosphoric acid groups, methacrylate } \\
\text { monomers, alkaline (basic) fillers; silanated fillers; initiator components; } \\
\text { stabilizers; pigments; rheological additives }\end{array}$ \\
\hline TheraCem & $\begin{array}{l}\text { BISCO, Schaumburg, } \\
\text { IL, USA }\end{array}$ & $\begin{array}{l}\text { Calcium base filler, glass filler, 10-MDP, bisphenol A diglycidylmethacrylate, } \\
\text { dimethacrylates, 2-hydroxyethyl methacrylate, ytterbium flüoride, initiator, } \\
\text { amorphous silica }\end{array}$ \\
\hline Panavia SA Cement Plus & $\begin{array}{l}\text { Kuraray Noritake, } \\
\text { Okayama, Japan }\end{array}$ & $\begin{array}{l}\text { 10-MDP, Bis-GMA, TEGDMA, HEMA, hydrophobic aromatic dimethacrylate; } \\
\text { hydrophobic aliphatic dimethacrylate, silanated barium glass filler, silanated } \\
\text { colloidal silica, di-camphorquinone, peroxide, catalysts, surface treated sodium } \\
\text { fluoride, accelerators, pigments }\end{array}$ \\
\hline G-Cem LinkAce & $\begin{array}{l}\text { GC Corporation, } \\
\text { Tokyo, Japan }\end{array}$ & $\begin{array}{l}\text { UDMA, dimethacrylate, fluoroalumino silicate glass, initiator, pigment, silicone } \\
\text { dioxide, inhibitor }\end{array}$ \\
\hline PermaCem 2.0 & $\begin{array}{l}\text { DMG, Hamburg, } \\
\text { Germany }\end{array}$ & Barium glass, Bis-GMA, pigments, additives, catalysts \\
\hline BisCem & $\begin{array}{l}\text { BISCO, Schaumburg, } \\
\text { IL, USA }\end{array}$ & $\begin{array}{l}\text { Bis-GMA, uncured dimethacrylate monomer, glass filler, phosphate acidic } \\
\text { monomer }\end{array}$ \\
\hline SmartCem 2 & $\begin{array}{l}\text { Dentsply Caulk, } \\
\text { Milford, DE, USA }\end{array}$ & $\begin{array}{l}\text { UDMA, di- and tri-methacrylate resins, phosphoric acid modified acrylate } \\
\text { resin, barium boron fluoroaluminosilicate glass, organic peroxide initiator, } \\
\text { camphorquinone photoinitiator, phosphene oxide photoinitiator, accelerators, } \\
\text { butylatedhydroxytoluene, UV stabilizer, titanium dioxide, iron oxide, } \\
\text { hydrophobic amorphous silicon dioxide }\end{array}$ \\
\hline Maxcem Elite & $\begin{array}{l}\text { Kerr Corporation, } \\
\text { Orange, CA, USA }\end{array}$ & $\begin{array}{l}\text { GPDM, co-monomers (mono-, di-, and tri-functional), proprietary self-curing } \\
\text { redox activator, methacrylate monomers, water, acetone, and ethanol, inert } \\
\text { minerals and ytterbium fluoride }\end{array}$ \\
\hline ZenitCem & $\begin{array}{l}\text { President Dental, } \\
\text { Munich, Germany }\end{array}$ & Barium glass, Bis-GMA, pigments, additives, catalysts \\
\hline Bifix SE & $\begin{array}{l}\text { Voco GmbH, } \\
\text { Cuxhaven, Germany }\end{array}$ & UDMA, Bis-GMA, Gly-DMA, phosphate monomers, initatiors, stabilizer, glass \\
\hline
\end{tabular}

chamber (inner diameter, $3 \mathrm{~mm}$; height, $3 \mathrm{~mm}$ ) were placed on the zirconia surface and mixed selfadhesive dual-curing resin cements were applied into the molds following the manufacturers' instructions. Self-adhesive resin cements were light polymerized for $40 \mathrm{~s}$ with a light-emitting diode curing unit $\left(1,200 \mathrm{~mW} / \mathrm{cm}^{2}\right.$, Bluephase, Ivoclar Vivadent, Schaan, Liechtenstein). After the bonding procedures, the teflon molds were gently removed from the bonded specimens. All the resin-bonded zirconia specimens were stored in distilled water at $37^{\circ} \mathrm{C}$ for $24 \mathrm{~h}$ and then thermocycled 5,000 times between 5 and $55^{\circ} \mathrm{C}$ with a dwelling time of $30 \mathrm{~s}$ at each temperature. The SBS of the specimens were measured using a knife edge rod mounted on a universal test machine (TSTM 02500, Elista Ltd., i̇stanbul, Turkey) at a crosshead speed of $1 \mathrm{~mm} / \mathrm{min}$. The shear load at failure was recorded and the SBS was calculated using the following formula:
SBS $(\mathrm{MPa})=$ Failure Load $(\mathrm{N}) /$ Area $\left(\mathrm{mm}^{2}\right)$

Finally, the failure modes were examined under a strereomicroscope (Olympus SZ40; Olympus Optical Co., Tokyo, Japan). Failure types of the tested specimens were classified as adhesive, mixed, or cohesive.

\section{Statistical Analysis}

Statistical analysis was performed using SPSS 21.0 for Windows (SPSS Inc., Chicago, IL, USA). KolmogorovSmirnov and Levene tests were used to assess normal distribution of the SBS data and homogeneity of variances, respectively. The SBS data were statistically analyzed using two-way analysis of variance (ANOVA). Tukey's honestly significant difference (HSD) test and independent sample t-tests were used for pairwise comparisons. The significance level was set at $\alpha=0.05$ for all statistical tests. 


\section{Results}

The two-way ANOVA revealed an individual significant effect of both primer application and different self-adhesive cements on the SBS, as shown in Table $2(p<0.001)$. The mean and standard deviation values, and comparisons for the subgroups are shown in Table 3. Additionally, a box-plot graph is shown, with the distributions of SBS values including median, minimum, and maximum values of the groups (Figure 1). Primer application significantly increased the shear bond values in all cements $(p<0.001)$. The results of Tukey's HSD showed that Maxcem Elite had the highest SBS values in both primer-applied and non-applied groups $(p<0.05)$, whereas the SBS values of SmartCem 2, Bifix SE, and RelyX U200 cements were lower than those of the other cements $(p<0.05)$. Panavia SA Cement Plus had higher and TheraCem had lower SBS values compared to G-Cem LinkAce in the groups without primer application $(p<0.05)$, but no statistically difference was found between SBS values of these cements in primer-applied groups ( $p>0.05)$.
As shown in Figure 2, adhesive and mixed failure types were evident in all experimental groups, whereas no cohesive failure of the resin cement was observed. Mixed failures were more predominant in primed groups than in non-primed groups for each resin cement. In the primer-applied Maxcem Elite group, adhesive failure occurred in only one specimen, while non-primed Bifix SE and SmartCem 2 showed the highest adhesive failure rates, in nine specimens.

\section{Discussion}

The present study was designed to compare the SBS of different self-adhesive resin cements to a monolithic zirconia ceramic with or without application of a MDP-containing primer. The two null hypotheses were rejected because use of different resin cements or use of primer application significantly changed the SBS values. Primer application resulted in higher SBS values for each resin cement.

All the zirconia ceramic surfaces were subjected to airborne-particle abrasion in the study. It has

\begin{tabular}{|c|c|c|c|c|c|}
\hline & Type III sum of squares & df & Mean square & $\mathbf{F}$ & $p$ \\
\hline Cement & 1205.216 & 9 & 133.913 & 146.953 & $<0.001$ \\
\hline Primer & 881.790 & 1 & 881.790 & 967.659 & $<0.001$ \\
\hline Cement $\mathrm{x}$ Primer & 48.637 & 9 & 5.404 & 5.930 & $<0.001$ \\
\hline
\end{tabular}

\begin{tabular}{|c|c|c|c|c|c|c|}
\hline & \multicolumn{3}{|c|}{ Primer + } & \multicolumn{3}{|c|}{ Primer - } \\
\hline & Mean & SD & * & Mean & SD & * \\
\hline SmartCem 2 & 8.56 & 0.91 & $A, a$ & 4.03 & 0.70 & $A, b$ \\
\hline Bifix SE & 8.72 & 0.70 & A, a & 4.23 & 0.48 & $A, b$ \\
\hline RelyX U200 & 9.44 & 0.90 & A, a & 4.20 & 0.88 & $A, b$ \\
\hline Zenitcem & 11.09 & 0.91 & $\mathrm{~B}, \mathrm{a}$ & 8.72 & 0.56 & $C D, b$ \\
\hline TheraCem & 12.67 & 1.31 & C, a & 6.59 & 0.75 & $\mathrm{~B}, \mathrm{~b}$ \\
\hline G-cem LinkAce & 12.77 & 1.09 & $C, a$ & 8.23 & 0.99 & $c, b$ \\
\hline Panavia SA Cement Plus & 12.97 & 1.36 & $C, a$ & 9.81 & 1.01 & $D, b$ \\
\hline PermaCem 2.0 & 13.11 & 1.30 & $C, a$ & 9.32 & 1.19 & $C D, b$ \\
\hline BisCem & 13.79 & 0.86 & C, a & 9.91 & 1.15 & $D, b$ \\
\hline Maxcem Elite & 16.08 & 0.67 & $\mathrm{D}, \mathrm{a}$ & 12.18 & 0.73 & $E, b$ \\
\hline \multicolumn{7}{|c|}{$\begin{array}{l}\text { SD: Standard deviation } \\
\text { *Same uppercase letters in the same column (Tukey's HSD, p>0.05) and same lowercase letters in the same row (Independent samples t-tests, } p>0.05 \text { ) } \\
\text { denote subgroups that were not significantly different }\end{array}$} \\
\hline
\end{tabular}


been reported that airborne-particle abrasion under relatively higher pressures might compromise the mechanical strength of the zirconia ceramic, and that to avoid possible excessive surface damage, zirconia should be abraded using $50-\mu \mathrm{m}$ particles with a pressure of 2.5 bar or less (22). The alumina blasting parameters used in the present study have also been used in other studies $(17,23,24,35)$, and allow sufficient surface roughening and cleaning (22). Such surface treatment may increase the surface area, surface energy, and wettability, thus facilitating the resin to flow into the surface $(6,16)$. Moreover, the

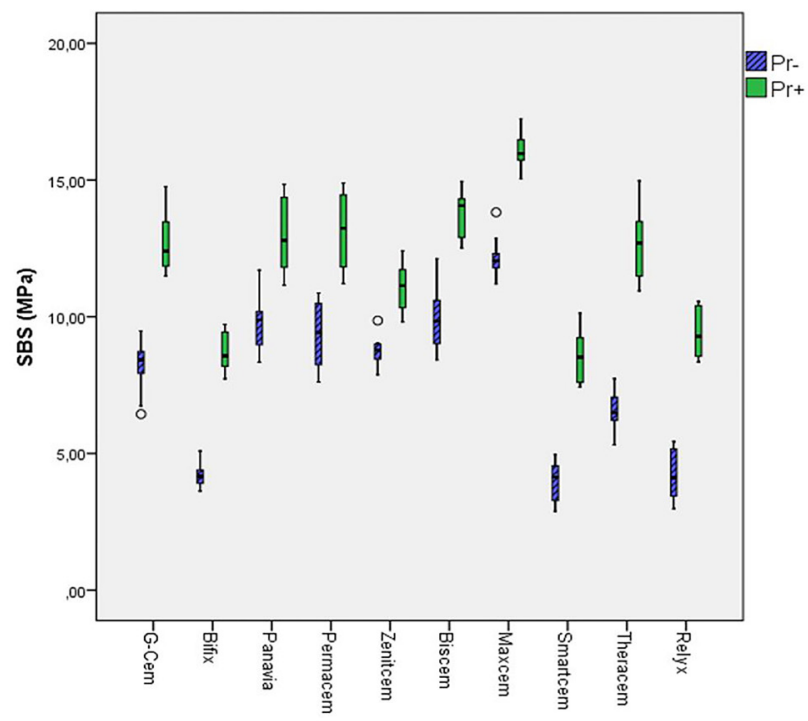

Figure 1. Box-plot graph based on the SBS values of 20 subgroups $(n=10)$. Data are presented as median and $1^{\text {st }}$ and $3^{\text {rd }}$ quartile. The median is shown with a horizontal line within the box. The maximum and minimum values are illustrated with the upper and lower strokes. ${ }^{0}$ marks outliers

SBS: Shear bond strength

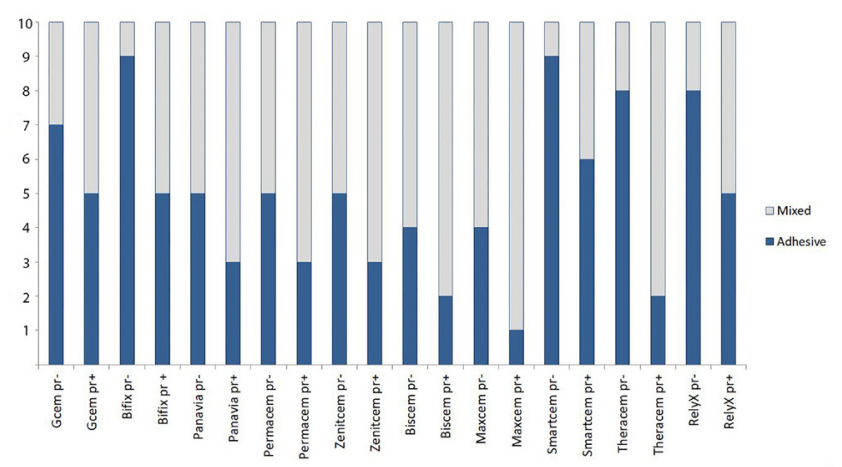

Figure 2. The failure types in each group. The vertical axis of the graph indicates the number of specimens and the bars represent the ratio between the failure types abrasion process may generate hydroxyl groups on the Y-TZP surface that enable chemical bonding (34). In one clinical trial (36), air-abrasion was not performed and MDP-containing luting cements and primers were used on the as-machined zirconia surface; the authors reported a debonding rate of $13.3 \%$ over an observation time of 53 months. Similarly, findings of a study by de Souza et al. (29) revealed that the application of MDP-containing primers and adhesives to a non-airborne-particle-abraded zirconia surface increased the initial resin bond strength but no stable bonding was present after six months of water storage. Therefore, omitting the abrasion process appears to increase the risk of debonding when using a MDP monomer. In a meta-analysis of bonding to zirconia, Inokoshi et al. (31) also concluded that the combination of mechanical and chemical pretreatments contributed to durability of resin bonding. Additionally, the study emphasized that application of MDP-based primer after $\mathrm{Al}_{2} \mathrm{O}_{3}$ blasting may lead to increased aging resistance of the cement-zirconia bond (31), but that further investigation is needed.

MDP-based ceramic primer application significantly increased the SBS of all self-adhesive resin cements used in the present study. Further, increased ratios of mixed failure types observed in primer-applied groups supported the findings. The positive influence of priming may be due to enhanced physicochemical interaction between resin and zirconia (37), and also due to the increased wettability of the zirconia surface (31). Phosphoric groups in MDP yield certain chemical reactions with hydroxyl groups of zirconia $(37,38)$, while the decyl group in MDP prevents water penetration at the interface between the dihydrogen phosphate and metal oxide layers (39). This was confirmed in a recent study by Yang et al. (30), in which the durability of resin bonding was evaluated and a remarkable reduction in SBS in all experimental groups was seen after long-term artifical aging, with the exception of groups treated with an MDP-based zirconia primer. In another investigation, Yagawa et al. (26) concluded that application of primers containing MDP ensured durable bond strength after 5,000 thermocycles; the authors also reported that MDPbased primers provide higher bond strengths than priming agents containing carboxylic monomer (4META). In agreement with the results of the present study, those in a study by Kitayama et al. (6) indicated 
that primers containing a phosphate ester monomer were effective in improving bonding of resin cements to zirconia. On the other hand, the authors also concluded that even without primer application, the MDP-containing resin cement was effective in bonding. Another study conducted by Wegner and Kern (40) on two-year tensile bond strength showed that the functional phosphate ester groups in MDP yielded water-resistant chemical adhesion with the zirconia; MDP-based resin cements are recommended in clinical practice based on their results. However, these findings are not consistent with our results, because there was no association between the MDP content of resin cements and the bond strength values. The results of the present study indicate that MDP-containing self-adhesive resin cements (TheraCem and Panavia SA Cement Plus) did not have the highest SBS values. Similarly, in a previous study, de Souza et al. (41) reported that application of an MDP-containing primer may increase the bond strength; however, an MDP-based luting system did not increase bond strength to zirconia; in addition, the aged specimens showed lower values. In agreement, Zhao et al. (25) also showed no positive effect of the presence of MDP in resin cement on SBS values after long-term aging. As stated in earlier studies, the lack of correlation between MDP content of resin cement and higher bond strength values may be related to the concentration of MDP in the resins and differences in viscosities of the cements $(29,42)$. In another study, de Souza et al. (29) compared the bond strength of MDPbased resin cement with that of a non-MDP-containing resin cement. The similarity in bond strength values between these resin cements have been attributed to relatively higher viscosity of the MDP-containing resin cement used in the above study. Resin cements with low viscosity can easily flow into the microporosities of the air-particle abraded zirconia surface; thus, a larger adhesive surface can be obtained (42). The SBS values showed significant differences among the 10 different commercially available resin cements in the present study. Regardless of the primer application, Maxcem Elite showed higher SBS values and Smart CEM showed lower SBS values compared to the others. As discussed previously, other factors that may influence bonding capacity include mechanical properties, wetting capacity, and variation in chemical composition of different luting cements (29). In addition, Thompson et al. (16) highlighted the fact that the composition of zirconia ceramics could influence the resin bond strength. The present study mainly focused on the effect of priming combined with different resin cements and therefore, a single standardized monolithic zirconia was used as the ceramic material to understand these effects more clearly.

Thermocycling is a frequently used in vitro study method because it may influence bonding, especially in high-strength ceramics $(26,40)$. This method can imitate clinical conditions by inducing thermal stresses and hydrolytic effects (43). Therefore, in the present study, 5,000 thermal cycles in water beween $5-55^{\circ} \mathrm{C}$ were done. Even if these parameters were considered as an appropriate aging regimen as reported in a previous study (26), long-term aging conditions should also be investigated. The other limitation of our study was that only Clearfil Ceramic Primer was used as MDP-containing primer. This primer is known to contain a silane agent. Future studies should be focussed on other types of primers that have different compositions, or on usage of such silanecontaining MDP-based primers in combination with tribochemical silica-coating techniques. Finally, the in vitro design of this study may not fully represent the intra-oral conditions. For instance, the resin cement thickness formed in clinical conditions could not be simulated, which is also an important factor in bonding efficiency (16). Therefore, further investigations are needed to understand the effects of zirconia primers on the bonding of different resin cements in both in vivo and in vitro conditions using different materials, test designs, and aging conditions.

\section{Conclusion}

Under the conditions of the present in vitro study, the following conclusions can be made:

1) Application of an MDP-containing primer was found to be effective in improving the SBS of resin cements to airborne-particle-abraded zirconia.

2) Regardless of primer use, SBS values of various self-adhesive resin cements were significantly different from each other.

3) There was no association between the MDP content of the resin cements and the SBS values because MDP-based resin cements used did not result in the highest bond strengths. 
4) Mixed/adhesive failure type ratios for each resin cement were increased due to the application of an MDP-based primer.

Ethics

Ethics Committee Approval: This article does not contain any studies with human participants or animals performed by any of the authors.

Informed Consent: For this type of study, informed consent is not required.

Peer-review: Externally peer-reviewed.

\section{Authorship Contributions}

Concept: M.T.Y., M.B.D., T.G., Design: Y.O., M.T.Y, M.B.D., Supervision: M.T.Y., Y.O., Fundings: M.T.Y., Data Collection or Processing: T.G., M.T.Y., M.B.D., Analysis or Interpretation: Y.O., M.T.Y., M.B.D., T.G., Literature Search: Y.O, M.B.D., T.G., Writing: Y.O., Critical Review: Y.O., M.T.Y., M.B.D., T.G.

Conflict of Interest: No conflict of interest was declared by the authors.

Financial Disclosure: This study was supported by the Scientific Research Project Council of Selçuk University, Turkey (17401097).

\section{References}

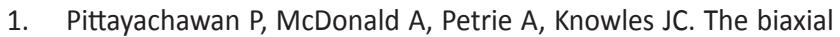
flexural strength and fatigue property of Lava Y-TZP dental ceramic. Dent Mater 2007; 23: 1018-29.

2. Denry I, Kelly JR. State of the art of zirconia for dental applications. Dent Mater 2008; 24: 299-307.

3. Piconi C, Maccauro G. Zirconia as a ceramic biomaterial. Biomaterials 1999; 20: 1-25.

4. Kosmac T, Oblak C, Jevnikar P, Funduk N, Marion L. Strength and reliability of surface treated Y-TZP dental ceramics. J Biomed Mater Res 2000; 53: 304-13.

5. Manicone PF, Rossi lommetti P, Raffaelli L. An overview of zirconia ceramics: basic properties and clinical applications. J Dent 2007; 35: 819-26.

6. Kitayama S, Nikaido T, Takahashi R, Zhu L, Ikeda M, Foxton RM, et al. Effect of primer treatment on bonding of resin cements to zirconia ceramic. Dent Mater 2010; 26: 426-32.

7. Preis V, Letsch C, Handel G, Behr M, Schneider-Feyrer S, Rosentritt $M$. Influence of substructure design, veneer application technique, and firing regime on the in vitro performance of molar zirconia crowns. Dent Mater 2013; 29: 113-21.

8. Alessandretti R, Borba M, Benetti P, Corazza PH, Ribeiro R, Della Bona A. Reliability and mode of failure of bonded monolithic and multilayer ceramics. Dent Mater 2017; 33: 191-7.

9. Sailer I, Makarov NA, Thoma DS, Zwahlen M, Pjetursson BE. All-ceramic or metal-ceramic tooth-supported fixed dental prostheses (FDPs)? A systematic review of the survival and complication rates. Part I: Single crowns (SCs). Dent Mater 2015; 31: 603-23.
10. Pjetursson BE, Sailer I, Makarov NA, Zwahlen M, Thoma DS. All-ceramic or metal-ceramic tooth-supported fixed dental prostheses (FDPs)? A systematic review of the survival and complication rates. Part II: Multiple-unit FDPs. Dent Mater 2015; 31: 624-39.

11. Venezia P, Torsello F, Cavalcanti R, D’Amato S. Retrospective analysis of 26 complete-arch implant-supported monolithic zirconia prostheses with feldspathic porcelain veneering limited to the facial surface. J Prosthet Dent 2015; 114: 506-12.

12. Nakamura K, Harada A, Inagaki R, Kanno T, Niwano Y, Milleding $P$, et al. Fracture resistance of monolithic zirconia molar crowns with reduced thickness. Acta Odontol Scand 2015; 73: 602-8.

13. Edelhoff D, Ozcan M. To what extent does the longevity of fixed dental prostheses depend on the function of the cement? Working Group 4 materials: cementation. Clin Oral Implants Res 2007; 18: 193-204.

14. Blatz MB, Sadan A, Kern M. Resin-ceramic bonding: a review of the literature. J Prosthet Dent 2003; 89: 268-74.

15. Guazzato M, Albakry M, Ringer SP, Swain MV. Strength, fracture toughness and microstructure of a selection of all-ceramic materials. Part II. Zirconia-based dental ceramics. Dent Mater 2004; 20: 449-56.

16. Thompson JY, Stoner BR, Piascik JR, Smith R. Adhesion/ cementation to zirconia and other non-silicate ceramics: where are we now? Dent Mater 2011; 27: 71-82.

17. Wolfart M, Lehmann F, Wolfart S, Kern M. Durability of the resin bond strength to zirconia ceramic after using different surface conditioning methods. Dent Mater 2007; 23: 45-50.

18. Kumbuloglu O, Lassila LV, User A, Vallittu PK. Bonding of resin composite luting cements to zirconium oxide by two air-particle abrasion methods. Oper Dent 2006; 31: 248-55.

19. Zhang Y, Lawn BR, Rekow ED, Thompson VP. Effect of sandblasting on the long-term performance of dental ceramics. J Biomed Mater Res B Appl Biomater 2004; 71: 381-6.

20. Zhang $Y$, Lawn BR, Malament KA, Van Thompson P, Rekow ED. Damage accumulation and fatigue life of particle-abraded ceramics. Int J Prosthodont 2006; 19: 442-8.

21. Guazzato M, Quach L, Albakry M, Swain MV. Influence of surface and heat treatments on the flexural strength of Y-TZP dental ceramic. J Dent 2005; 33: 9-18.

22. Kern M. Bonding to oxide ceramics-laboratory testing versus clinical outcome. Dent Mater 2015; 31: 8-14.

23. Kern M, Barloi A, Yang B. Surface conditioning influences zirconia ceramic bonding. J Dent Res 2009; 88: 817-22.

24. Yang B, Barloi A, Kern M. Influence of air-abrasion on zirconia ceramic bonding using an adhesive composite resin. Dent Mater 2010; 26: 44-50.

25. Zhao L, Jian YT, Wang XD, Zhao K. Bond strength of primer/ cement systems to zirconia subjected to artificial aging. J Prosthet Dent 2016; 116: 790-6.

26. Yagawa S, Komine F, Fushiki R, Kubochi K, Kimura F, Matsumura H. Effect of priming agents on shear bond strengths of resin-based luting agents to a translucent zirconia material. J Prosthodont Res 2018; 62: 204-9. 
27. Koizumi $H$, Nakayama $D$, Komine $F$, Blatz $M B$, Matsumura $H$. Bonding of resin-based luting cements to zirconia with and without the use of ceramic priming agents. J Adhes Dent 2012; 14: 385-92.

28. Dias de Souza GM, Thompson VP, Braga RR. Effect of metal primers on microtensile bond strength between zirconia and resin cements. J Prosthet Dent 2011; 105: 296-303.

29. de Souza G, Hennig D, Aggarwal A, Tam LE. The use of MDPbased materials for bonding to zirconia. J Prosthet Dent 2014; 112: 895-902.

30. Yang L, Chen B, Xie H, Chen Y, Chen Y, Chen C. Durability of Resin Bonding to Zirconia Using Products Containing 10-Methacryloyloxydecyl Dihydrogen Phosphate. J Adhes Dent 2018; 20: 279-87.

31. Inokoshi M, De Munck J, Minakuchi S, Van Meerbeek B. Metaanalysis of bonding effectiveness to zirconia ceramics. J Dent Res 2014; 93: 329-34.

32. de Oyagüe RC, Monticelli F, Toledano M, Osorio E, Ferrari M, Osorio R. Influence of surface treatments and resin cement selection on bonding to densely-sintered zirconium-oxide ceramic. Dent Mater 2009; 25: 172-9.

33. Lee SE, Bae JH, Choi JW, Jeon YC, Jeong CM, Yoon MJ, et al. Comparative Shear-Bond Strength of Six Dental Self-Adhesive Resin Cements to Zirconia. Materials 2015; 8: 3306-15.

34. Ahn JS, Yi YA, Lee Y, Seo DG. Shear Bond Strength of MDPContaining Self-Adhesive Resin Cement and Y-TZP Ceramics: Effect of Phosphate Monomer-Containing Primers. Biomed Res Int 2015; 2015: 389234.
35. Lehmann F, Kern M. Durability of resin bonding to zirconia ceramic using different primers. J Adhes Dent 2009; 11: 479-83.

36. Sailer I, Hämmerle $\mathrm{CH}$. Zirconia ceramic single-retainer resinbonded fixed dental prostheses (RBFDPs) after 4 years of clinical service: a retrospective clinical and volumetric study. Int J Periodontics Restorative Dent 2014; 34: 333-43.

37. Chen L, Suh BI, Brown D, Chen X. Bonding of primed zirconia ceramics: evidence of chemical bonding and improved bond strengths. Am J Dent 2012; 25: 103-8.

38. Nagaoka N, Yoshihara K, Feitosa VP, Tamada Y, Irie M, Yoshida Y, et al. Chemical interaction mechanism of 10-MDP with zirconia. Sci Rep 2017; 7: 45563.

39. Feitosa VP, Sauro S, Ogliari FA, Ogliari AO, Yoshihara K, Zanchi CH, et al. Impact of hydrophilicity and length of spacer chains on the bonding of functional monomers. Dent Mater 2014; 30: 317-23.

40. Wegner SM, Kern M. Long-term resin bond strength to zirconia ceramic. J Adhes Dent 2000; 2: 139-47.

41. de Souza GM, Silva NR, Paulillo LA, De Goes MF, Rekow ED, Thompson VP. Bond strength to high-crystalline content zirconia after different surface treatments. J Biomed Mater Res B Appl Biomater 2010; 93: 318-23.

42. Al-Harbi FA, Ayad NM, Khan ZA, Mahrous AA, Morgano SM. In vitro shear bond strength of Y-TZP ceramics to different core materials with the use of three primer/resin cement systems. J Prosthet Dent 2016; 115: 84-9.

43. Schmid-Schwap M, Graf A, Preinerstorfer A, Watts DC, Piehslinger $E$, Schedle A. Microleakage after thermocycling of cemented crowns--a meta-analysis. Dent Mater 2011; 27: 855-69. 